
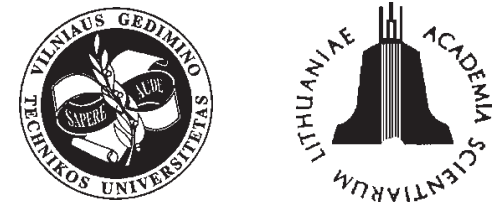

ISSN 1392-3730 print / ISSN 1822-3605 online

JOURNAL OF CIVIL ENGINEERING AND MANAGEMENT

http:/www.jcem.vgtu.lt

2006, Vol XII, No 1, 51-56

\title{
AN ITERATIVE ASSESSMENT CONCEPT FOR BUILDING DESIGN BASED ON THE ECO-FACTOR
}

\author{
Henrik Brohus and Erik Bjørn \\ Dept of Civil Engineering, Aalborg University, \\ Sohngaardsholmsvej 57,DK-9000 Aalborg, Denmark.E-mail: hb@bt.aau.dk \\ Received 26 June 2005, accepted 18 Dec 2005
}

\begin{abstract}
Problems in office buildings are often related to the design and control of the indoor environment and of the building as an energy system. The often interconnected nature of the above two issues is important to take into account, since, for instance, internal and external heat loads, temperatures, and air change rates affect both energy use and indoor comfort. Thus, to avoid the indoor climate problems, it is essential that energy optimisation is integrated with assessment of indoor climate. An assessment concept based on the so-called Eco-factor has been developed; it can assist building designers in creating solutions of these problems. The assessment concept is meant to be an integral part of new design guidelines for office buildings, which aim to achieve energy efficient buildings with a good indoor comfort and low environmental impact. The building designers have different needs at different stages of the design process. For this reason, the assessment concept makes use of the Eco-factor tool, which is defined so input can be based on both simple and advanced calculations in early and later phases of design, respectively, while still delivering the same output.
\end{abstract}

Keywords: building design, assessment concept, indoor climate, energy consumption, environmental impact, decisionmaking, Eco-factor.

\section{Introduction}

\subsection{Aims and scope of the assessment concept}

The main objective of the concept is to facilitate the building of energy efficient office buildings with desired indoor comfort and low environmental impact. The approach is to consider the complete energy system of a building (the total system and functionality of the building and its installations). The concept influences all stages in the building process, from idea stage to a real building, and aims to increase in all stages the knowledge of the building's complete energy system. The assessment concept enables the assessment and optimisation of energy use in the design/planning of buildings with integrated energy solutions. The analysis will focus on the energy use due to conditioning of the indoor environment of the building in the operation phase, including the environmental impact.

The main purposes of the assessment concept can be summarised as:

- The main target group are consultants and architects.

- Decision concept: assessment of the complete energy system, both the building design and different technical solutions.

- Focused concept: energy use, indoor comfort and environmental impact in operation phase.
- Design concept applicable at all stages in the building process.

- New application of "traditional simulation programs".

- Qualified judgement of output (eg just " $\mathrm{kWh}$ " vs "kWh" from different energy sources and the indoor environmental impact).

- Applicable for multidimensional optimisation, sensitivity analysis etc.

The objective of the assessment tool is to provide a tool - or rather a framework - for evaluation and optimisation of different energy sources and techniques in the design phase. The assessment method will encourage that well-validated existing simulation software tools are used since the assessment tool aims to be for practice (at a semi-advanced level). The following paragraph briefly introduces the Eco-factor tool after which the assessment concept is defined.

\subsection{The Eco-factor methodology}

The Eco-factor methodology is an evaluation method that incorporates environmental effects of energy use with thermal and atmospheric indoor climate in a score on a common scale from $0-100 \%$, the so-called Eco-factor. It includes both the "internal" aspect of energy use (ie 


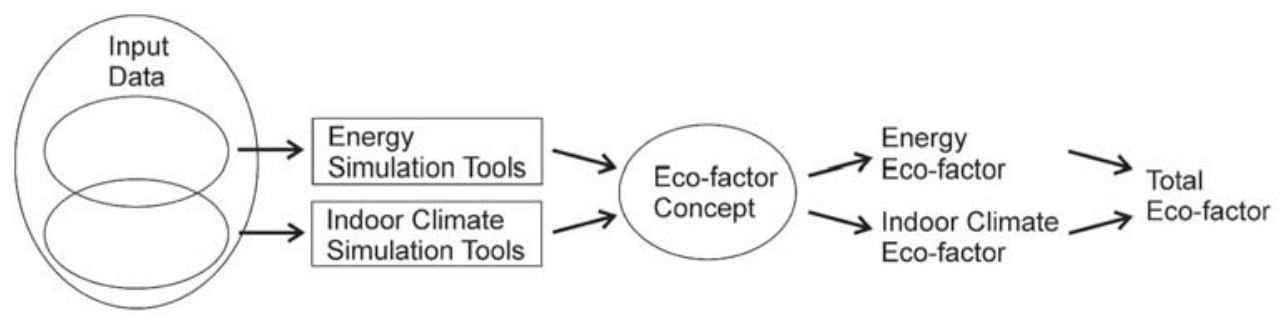

Fig 1. Calculation of the Eco-factor requires the assistance of some existing energy and indoor climate tools. The quality and detail of both the input data and the simulation tools increases as the design process progresses, but the evaluation method remains the same

indoor comfort issues) and "external" aspects of energy use (ie environmental issues) [1-5]. The Eco-factor is based on one part considering an Energy Eco-factor, another part considering an Indoor Climate Eco-factor; both combined in a Total Eco-factor (Fig 1). The Ecofactor concentrates on the running "costs" (here, "costs" is defined broadly to comprise also environmental impact). In that way the most important part of the environmental impact is considered without heavy, laborious and costly calculations. The use of the Eco-factor tool is in effect a way of including the major part of the environmental loads from the building life cycle without having to actually perform a complete LCA on the building (for instance, [6]). The Eco-factor methodology is an integrated part of the assessment concept that is presented in the subsequent paragraphs.

\section{Methods}

\subsection{The assessment concept}

In the present assessment concept, design is thought to be an iterative process where the solution is evaluated with the Eco-factor tool at the end of each iteration ([7]). The concept is inspired by various existing assessment tools and methodologies [8-14]. The Eco-factor tool seeks to meet the above-mentioned requirements to a proper decision-making tool by supplying:

- A common reference frame, which remains the same at all levels of design,

- Flexibility regarding input data (both regarding accuracy and models),

- Advice to the designer,

- A tool that facilitates communication between the different parties in the building process.

The idea is to give the designers and building owners an immediately understandable, graphic impression of the overall performance, as well as the performance of individual aspects of the design and, thus, to give indications as to the parts of the design that are not performing well. This will help designers and owners not to be persuaded by clever details or vendors, but instead concentrate on a solution that is adjusted to the climate and use of the building, and which works well when considered as a total energy system.
The concept works on two levels. The first and most "simple" level, the concept design level is applied to get a fast overview and provide intelligent suggestions of alternative building designs (Fig 2). This level consists of guidance for scanning, coarse methods, principles, catalogues etc, that will help provide intelligently design suggestions of the building without doing any detailed simulations. The suggestions may be sketches/scenarios of the building design.

This pre-design level may consist of parameter studies for net heating and cooling energy use during one year for a reference building. Parameter studies for indoor comfort where different cases are studied, day-night, winter-summer etc. Input from these parameter studies will together with installation energy effectiveness and choice of energy sources give an estimation of the Eco-factor. The results give guidance on how different parameters affect the indoor comfort, the energy consumption and the Eco-factor for a reference case, and do not tell directly how these parameters influence a specific building.

The second and "advanced" level, the detailed design level, is aimed for the consultants to do detailed designs on a few chosen cases. This level comprises the systematic application of advanced simulation tools preferably existing and well-known tools. The concept is not concerned with the application of new simulation tools, but with the application of existing tools in a new frame of reference using the Eco-factor methodology.

Each of the above levels consists of two phases: a design phase and an assessment phase. In the pre-design phase the building is designed by two or three sketches going into more detail on a chosen overall solution in the advanced design phase. These building suggestions are assessed according to the Eco-factor method. A high score will indicate that the building has a good indoor comfort, low environmental impact or use of renewable energy sources - or a combination of the three factors.

If the suggested building design and technical solution give satisfactory results in the assessment phase, the concept will lead to the next level. If not, the process will go back to the design phase. This process will continue in an iterative way until a desirable Eco-factor is achieved for a suggestion with reasonable costs. The concept is summarised in Fig 2. 


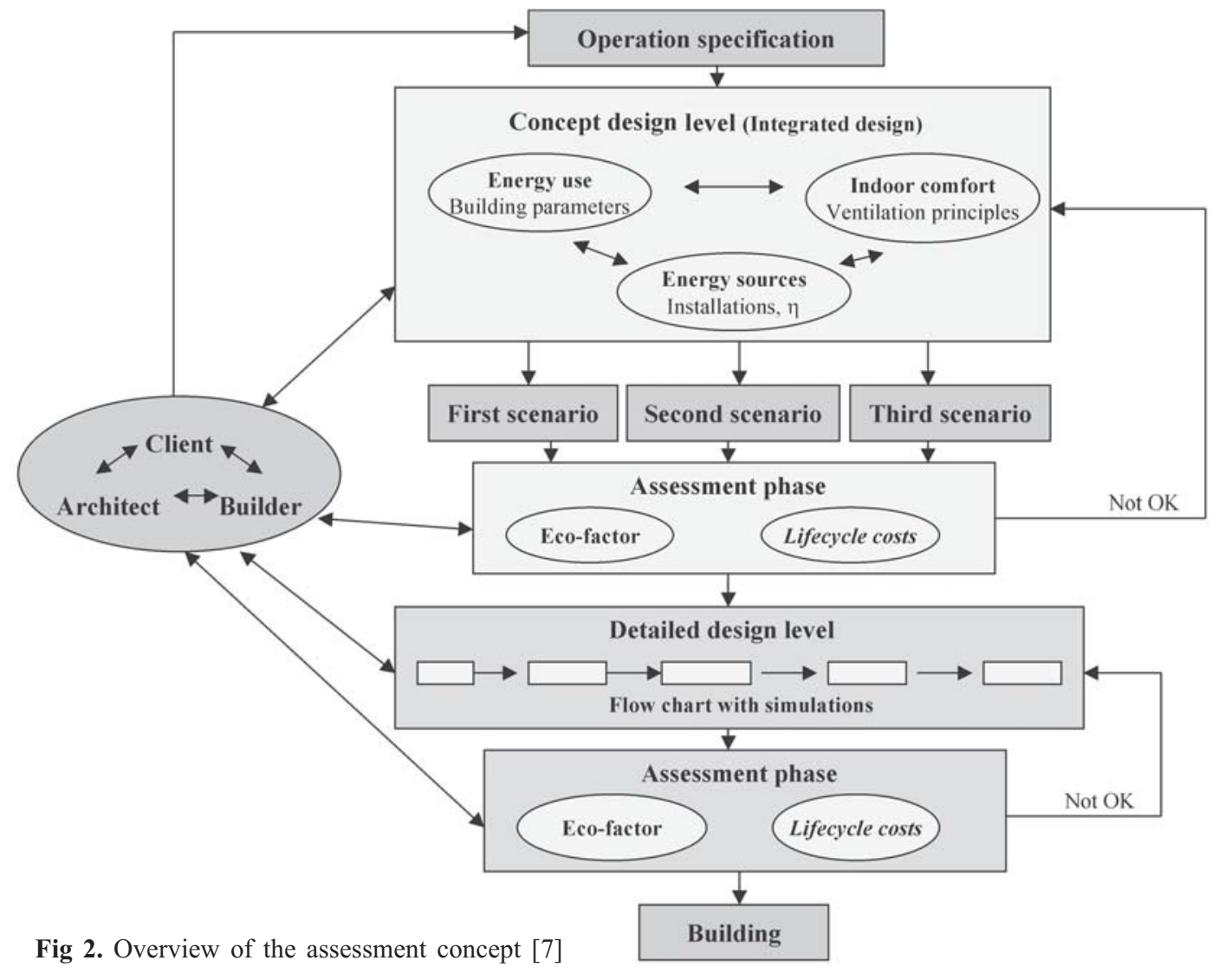

\section{Results}

\subsection{Example of concept application}

A client has decided to build a new building or retrofit an old one. He informs an architect and a builder of his operation requirements (functionality, space, flexibility, indoor comfort, temperature variation etc). He also requires that the building should obtain desired indoor comfort with low energy use, with optimised use of renewable energy sources. The latter requirements can be met using the present concept.

In the pre-design level of the assessment concept he can see how different design parameters affect the energy consumption and the indoor climate. For example, he finds that an increase in room height may allow a reduced airflow for ventilation, due to a buffer effect, reducing the corresponding heat loss. Another example is an operation requirement that the variation of the indoor comfort should be sufficiently small. The concept will show that a building with a climate shield with high thermal capacity and exposed mass reduces the variation of the indoor temperature. On the other hand, changes of the indoor temperature will be more difficult to control rapidly due to the thermal capacity. It may require larger heating or cooling powers, which can be expensive.

Together with choices of energy sources and installations the architect suggests two or three choices of building designs and technical solutions that is discussed with the project-team. These choices are assessed both according to the Eco-factor method and perhaps a lifecycle cost analysis (LCC), too. If the project-team is satisfied with the assessments, the process continues to the advanced design level. If not, the architect has to come up with new suggestions.

Next step is to evaluate the design suggestions in a more advanced way by consultants. At this stage, advanced simulation of indoor comfort and energy use must be performed for the specific building. When all required data is available, the process continues to the assessment level and evaluates the building suggestions, using the Eco-factor method. The results indicate what choice is the most favourable in terms of environmental impact and indoor comfort.

\subsection{Application of assessment concept in design phases}

As Fig 2 shows, the assessment method is mainly focused on two distinct design steps, called "concept design" and "detailed design". However, before design commencement there is a project specification phase, which delivers important input for the following design. After design, the building is constructed and the operation phase begins, where monitoring of the operation takes place, and where it is usually necessary to make some adjustments and "tuning" of the building systems, and where the automatic control system must make continuous choices regarding, eg temperatures and airflows.

It is intended that the Eco-factor tool can be a support during all phases, including pre-design and operation, ie four separate phases in total (Table 1). 
Table 1. The Eco-factor may be used in four different phases of building design

\begin{tabular}{l|l}
\hline Phase & Use of Eco-factor tool \\
\hline $\begin{array}{l}\text { Operation } \\
\text { specification }\end{array}$ & Indoor climate and energy goals \\
\hline Concept design & Concept assessment and redefinition \\
\hline Detailed design & Design assessment and redefinition \\
\hline $\begin{array}{l}\text { Construction and } \\
\text { operation }\end{array}$ & $\begin{array}{l}\text { Operation evaluation. Fault correction. } \\
\text { Control optimisation }\end{array}$ \\
\hline
\end{tabular}

\subsection{Operation specification}

At this design stage, very little is known. However, the Eco-factor can still be used to assist in defining design goals regarding environmental performance, namely, by way of presenting easily understandable scores for typical solutions, based on standard values (eg maximum energy use, minimum outdoor air change rate etc), or on values from experience or references (eg case studies of well-performing buildings). By using the Eco-factor to communicate results from experts to non-experts (typically the user), the intuitive simplicity of the scale is beneficial, since non-experts often do not have a reference frame for judging quality. In that way the result may serve as a future reference at later design stages. This step supplies necessary data for the concept design phase:

- Boundaries for

o Possible geometry of building,

o Floor area and occupancy, use of building,

o Temperature limits, air change rates etc.

- Environmental and economic goals.

- Environmental and economic characteristics of available energy sources.

- Definition of indoor climate design goals, eg taking a starting point $[15,16]$.

\subsection{Concept design}

The concept design level consists of parameter studies for energy use during one year for a reference building, and for indoor comfort where different design situations are studied, day-night, winter-summer, location in building etc. Rough parameter variations are carried out with simplified models, in order to get the general layout of the building clear. The Eco-factor tool can act as a general reference frame, to evaluate relative importance of different types of input. The tool can be used in an iterative process for identifying possibilities for improvement, for dismissing trivial issues, and for avoiding "pitfalls", where design initiatives on one issue (eg energy savings) has unintended side-effects on another (eg deteriorated thermal comfort).

\subsection{Detailed design level}

The main function of the Eco-factor in this phase is to help the design team to maintain overall focus. All necessary data is present, but it is easy to loose overview in the profusion of details. By calculating the Ecofactor for each solution, the team is forced to consider the total energy and indoor climate solution again, and to compare with design goals, which can be useful for keeping things in perspective, and not waste too many man-hours on relatively trivial issues. In this phase the most advanced and detailed tools are applied to assess the building performance regarding energy and indoor climate, see Fig 3 for examples. Important design choices: control strategies and systems, materials, building components (HVAC, lighting etc), location of inlet and exhaust devices for ventilation and optimisation or finetuning of the choices made in concept design.

\subsection{Construction and operation phase}

The Eco-factor may be used during operation, for optimisation of choices made by the building energy management system, but also for making choices regarding energy sources, which may change during the buildings service life with regard to availability, technology, and price. Input for the Eco-factor tool can be calculated from monitored data on: energy use, temperatures, $\mathrm{CO}_{2}$ concentrations, air velocities etc.

\subsection{Input for Eco-factor calculation}

In many cases, there is not a clear line between an "energy tool" and an "indoor climate tool". Many existing tools can be used to evaluate aspects of both design issues. From this follows that the input for the two parts of the Eco-factor can often be assessed by the same calculation tools, since it is more or less the same underlying physical processes, requiring the same underlying theoretical models. Indoor and outdoor temperatures, air change rates etc, both define the energy use and the indoor climate, simultaneously.

The data can be, and indeed must be, calculated by the use of several existing calculation tools. However, it is data which are already calculated or otherwise assessed in most cases, at least at some stage of the building process. The Eco-factor method seeks to compile the overall effect of these efforts and to create overview by simplifying and standardising the output to the decisionmaker, who can then better concentrate on making the best decision, instead of wasting valuable effort understanding and evaluating technical details. Furthermore, use of the Eco-factor tool may act as a "reminder" to the decision-makers that certain design criteria should be considered even at early stages of the process.

The assessment concept is flexible with regard to the choice of calculation or simulation tools, in order that it can be used both in pre-design (simple tools, low accuracy and detail, few resources required) and in detailed design (advanced tools, high accuracy and detail, many resources required). In fact, very similar tools can 
A

$$
c_{\text {supply }} \cdot m_{\text {air }}+m_{\text {pollution }}=c_{\text {exhaust }} \cdot m_{\text {air }}
$$

Where

$c_{\text {supply }}=$ Concentration level in supply air $[\mathrm{kg}$ pollution $/ \mathrm{kg}$ air $]$ $c_{\text {exhaust }}=$ Concentration level in exhaust air $[\mathrm{kg}$ pollution $/ \mathrm{kg}$ air $]$ $m_{\text {air }}=$ Mass flow of air (supply flow rate equals exhaust flow rate ) $[\mathrm{kg}$ air $/ \mathrm{s}]$ $m_{\text {pollution }}=$ Mass flow of pollution (supplied inside the room [ $\mathrm{kg}$ pollution $/ \mathrm{s}$ ]

B

Fig 3. Example of tools that may be applied at the detailed design level to assess the building performance regarding indoor air quality. A. Steady-state mass balance [no variation in time and space]. B. Dynamic/transient mass balance calculated in a Thermal Building Simulation programme (Left: Concentration distribution over time. Right: Cumulated concentration level for one zone). [Variation in time, simple flow model]. C. Dynamic/transient mass balance calculated in a Multizone programme (Left: Building model. Right: Concentration histogram for several zones). [Variation in time, advanced flow model]. D. Steady-state mass balance for a detailed flow field calculated in a Computational Fluid Dynamics programme (Left: Flow field in ventilated room. Right: concentration distribution). [No variation in time, detailed spatial distribution]
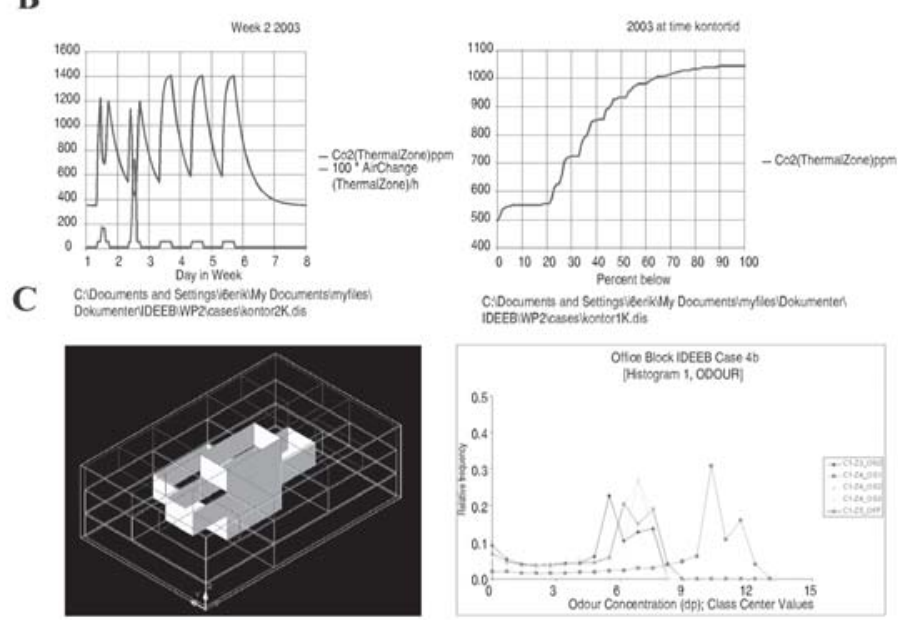

D
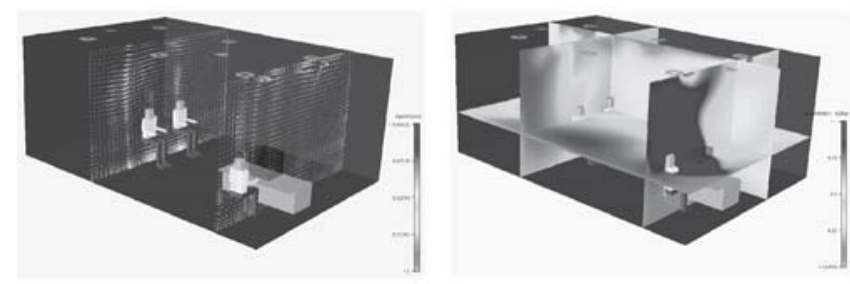

be used, based on the same underlying models (energy and mass balances), but with different levels of complexity. Advanced models are mainly used in the detailed design phase, see Fig 3 for examples, but with some possibility for including dynamic effects (especially for indoor temperatures) in the operative phase, in order to make reasonably accurate forecasts of the effects of a chosen control option.

\section{Discussion and conclusions}

An assessment concept based on the so-called Ecofactor has been developed, that can be useful for assisting building designers in creating intelligent building design. The assessment is meant to be an integral part of new design guidelines for office buildings, which aim to achieve energy efficient buildings with good indoor comfort and low environmental impact.

Problems in office buildings are often related to the design and control of the indoor environment and of the building as an energy system. The often interconnected nature of the above two issues is important to take into account, since, for instance, internal and external heat loads, temperatures, and air change rates affect both energy use and indoor comfort. Thus, to avoid the frequent indoor climate problems, it is essential that energy optimisation is integrated with assessment of indoor climate.

The building designers have different needs at different stages of the design process. For this reason, the assessment concept makes use of the Eco-factor tool, which is defined so that input can be based on both simple and advanced calculations in early and later phases of design, respectively, while still delivering the same output. It is found that the Eco-factor tool is a very useful decision-making tool. Especially, in case of design choices where conflicting goals must be evaluated at the same time. This may typically be related to the balance between costs (energy use) and benefits (indoor climate).

Getting a rough and early estimate, the design iterations converge faster toward the best integrated solution and the more detailed analyses are more likely to be aimed at the right problems. So, instead of constituting an additional calculation tool, requiring additional labour, the assessment concept with the Eco-factor may in fact be a time-saving device for building designers providing better solutions.

\section{Acknowledgment}

This paper is produced within the research project IDEEB (Intelligently Designed Energy Efficient Build- 
ings). IDEEB is partly financed by the European Commission within the 5th Framework Programme, ENERGIE.

The Eco-factor tool can be ordered free of charge upon requestbye-mail: hb@bt.aau.dk

\section{References}

1. Bjørn E. and Brohus H. The "Eco-factor", a design oriented environmental assessment tool. In: Proceedings of CIBSE/ASHRAE Worldwide Conference 2003, Session 3c, Edinburgh, UK, Sept 2003. ISBN 190328743X.

2. Bjørn E. and Brohus H. A design oriented indexing system for energy use and indoor climate. In: Proceedings of healthy buildings 2003, 7th Intern. Conf, Vol 2, p. $692-$ 697, Singapore, Dec 2003. ISBN 981-04-9974-4.

3. Bjørn E. and Brohus H. Overall evaluation of indoor climate and energy for alternative office designs using the Eco-factor. Journal of Civil Engineering and Management, Vol 12, No 1, 2006, p. 43-49. ISSN 1392-3730.

4. Bjørn E., Wahlström Å. and Brohus H. Eco-factor method, IDEEB Report No 2, SP Swedish National Testing and Research Institute, Sweden, Jan 2004. ISBN 91-7848-974-1.

5. Wahlström, Å. and Brohus, H. An Eco-factor method for assessment of building performance. In: Proceedings of the $7^{\text {th }}$ Nordic Building Physics Symposium 2005, Reykjavik, Iceland, June 13-15, 2005.

6. Cole, R. and Kernan, P. Life-cycle energy use in office buildings. Building and Environment, Vol 31, No 4, 1996, p. 307-317.

7. Brohus, H.; Bjørn, E.; Nielsen, A. and Wahlström, Å. Assessment concept for the building design process, IDEEB Report No 3, SP Swedish National Testing and Research Institute, Sweden, Dec 2004. ISBN 91-85303-24-0.
8. Balcomb, D.; Andresen, I. and Aggerholm, S. (eds). Multicriteria decision-making. MCDM-23. A method for specifying and prioritising criteria and goals in design. IEA Solar Heating and Cooling, Task 23: Optimisation of Solar Energy Use in Large Buildings. Draft version, Oct 12, 2001.

9. Cole, R. J. and Larsson, N. K. GBC '98 and GBTool: Background. Building Research and Information, Vol 27, Issue 4-5, 1999, p. 221-229.

10. Goedkoop, M. and Spriensma, R. The Eco-indicator 99, A damage oriented method for Life Cycle Impact Assessment, Methodology annex. Second edition, 17 Apr 2000, PRé Consultants B.V., Plotterweg 12, Amersfoort, The Netherlands, 2000.

11. IEA ECBCS Annex 31. Energy Related Environmental Impact of Buildings. http://www.ecbcs.org/Annexes/ annex31.htm

12. IEA Solar Heating and Cooling, Task 23. Optimisation of solar energy use in large buildings. http://www.iea-shc.org/ task23/index.html

13. Steen, B. A systematic approach to environmental priority strategies in product development (EPS). Version $2000-$ Models and data of the default method, CPM report 1999:5, Chalmers University of Technology, Environmental Systems Analysis, 1999.

14. Yates, A.; Baldwin, R.; Howard, N. and Rao, S. BREEAM 98 for offices. ISBN: 1860812384, BRE, UK, 1998.

15. EN CR 1752. Ventilation for Buildings - Design Criteria for the Indoor Environment, CR 1752:1998, CEN Dec 1998.

16. ISO-7730. SS-EN ISO 7730, Moderate thermal environments - Determination of the PMV and PPD indices and specification of the conditions for thermal comfort, 1991, International Standards Organisation, Geneva.

\section{ECO VEIKSNIU PAGRISTA ITERACINĖ PASTATO VERTINIMO KONCEPCIJA}

\section{H. Brohus, E. Bjørn}

\section{Santrauka}

Administraciniu pastatų problemos dažnai susijusios su pastato dizainu ir patalpos mikroklimato kontrole kaip energetinė sistema. Svarbu vertinti jų sąryši, nes, pavyzdžiui, išorinès ir vidinès šiluminès galios, temperatūros bei oro apykaita daro itaką ir energijos sąnaudoms, ir patalpos komfortui. Todèl, siekiant išvengti patalpų komforto problemų, energetinis optimizavimas yra dažnai integruojamas su patalpos mikroklimatu. Tam tikslui buvo sukurta vadinamoji ECO veiksnio vertinimo koncepcija, kuri gali padèti pastatų projektuotojams spręsti minėtąsias problemas. Vertinimo koncepcija turètų tapti administracinès paskirties projektavimo nurodymų sudètine dalimi, ir jos tikslas yra padèti projektuoti energetiškai efektyvius pastatus, palaikant juose tinkamas komfortines sąlygas ir drauge darant kuo mažiau žalos aplinkai. Pastato projektuotojai skirtingose projektavimo stadijose turi skirtingų poreikių. Dėl šios priežasties kaip priemonę vertinimo koncepcijoje reikètų naudoti ECO veiksni. Ši priemonè sukurta taip, kad paprastus skaičiavimus galima būtų atlikti pradineje projektavimo stadijoje, o sudėtingus skaičiavimus - vėlesnėse stadijose, kai tuo tarpu skaičiuojami tie patys rodikliai.

Raktažodžiai: pastato projektavimas, vertinimo koncepcija, patalpos mikroklimatas, energijos sąnaudos, ittaka aplinkai, sprendimų prièmimas, ECO veiksnys.

Erik BJØRN. Research Associate at the Dept of Civil Engineering, Aalborg University, Denmark. He holds a MSc and $\mathrm{PhD}$ in Indoor Environmental Engineering. Research interests: indoor climate and energy consumption, sustainable building design, LCA and environmental modelling.

Henrik BROHUS. Assoc Prof at the Dept of Civil Engineering, Aalborg University, Denmark. He holds a MSc and $\mathrm{PhD}$ in Indoor Environmental Engineering. Research interests: indoor climate and energy consumption, sustainable building design, advanced building simulation, computational fluid dynamics and stochastic modelling. 